\title{
Growth Response of Porang (Amorphophallus muelleri Blume) Grown with Different Sizes of Bulbils on Saline Soil
}

\author{
Muchdar Soedarjo $^{1^{*}}$, Yuliantoro Baliadi ${ }^{1}$, Fadjry Djufry ${ }^{2}$ \\ ${ }^{I}$ Indonesian Legume and Tuber Crops Research Institute Jl. Raya Kendalpayak Malang, East Java, Indonesia \\ ${ }^{2}$ Indonesian Agency for Agricultural Research and Development Jl. Ragunan 29, Pasar Minggu, Jakarta, \\ Indonesia
}

*Corresponding Authors: Muchdar Soedarjo, Indonesian Legume and Tuber Crops Research Institute Jl. Raya Kendalpayak Malang, East Java, Indonesia

\begin{abstract}
As an archipelago country, Indonesia harbors a large area of saline soils. Saline soils could be potential for farming of some plants. Porang (Amorphophallus muelleri Blume) has been cultivated by farmers in the forest as well as in nearby the forest. There have not been any studies about porang farming on saline soils. The present research work was carried out to evaluate the growth response of porang on saline soil. Porang seedlings were transplanted from previously germinated bulbil of different sizes $(1=1.88$ $\mathrm{g}, 2=2.83 \mathrm{~g}, 3=3.21 \mathrm{~g}, 4=3.75 \mathrm{~g}, 5=4.21 \mathrm{~g}, 6=4.78 \mathrm{~g}, 7=6.45 \mathrm{~g}$ and $8=9.10 \mathrm{~g} / \mathrm{bulbil}$ ) to a polyethylene bag containing saline soil (3 $\mathrm{kg}$ soil/bag). Each size of bulbil, as a treatment, was replicated three times in a completely randomized design. The research findings revealed that the growth of porang responded differently on saline soil, according to the bulbil size. The smallest size of bulbil was found to be the most susceptible to saline condition. At age of 15 days after transplanting, all plants from the smallest bulbil size died. Whilst, porang plants from the biggest bulbil size wilted. At age 22 days after transplanting, all porang plants from all sizes of bulbils severely wilted. Besides, the roots of all plants from all sizes of bulbils were damaged severely. The plant chemical analysis depicted much higher Na+ concentration in all parts of porang grown on salin soil than porang grown on Alfisol soil. Therefore, the results of the present research work suggest that porang plant is susceptible to saline soil and the susceptibility towards saline soil is due to toxicity of sodium.
\end{abstract}

Keywords: Amorphophallus muelleri Blume, saline, sodium, toxicity.

\section{INTRODUCTION}

The North Dakota State University introduced a defination of saline soil as the soil charaterized with excessive degree of soluble salts in the soil water and would negatively affect plant growth and even causes plant death (NDSU, 2020). The salts commonly found in saline soils are sodium, calcium and magnesium. Indonesia is known as one of the biggest archipelago country in the world. As a consequence, a large amount of land is surrounded by sea. The sea water would intrude further to the land off the seashore and causes an accumulation of salt, especially sodium, on the soil surface. Eventually, saline environment would establish on the land near and along the seashore. Therefore, Indonesia is expected to possess a huge amount of land situated with saline condition.

Farming on saline soils will be exposed to the saline-associated problems. Soybean grown on salin soils in East Java showed saline toxicity symptoms, growth retardation, significant yield reduction and a failure of plant harvest (Sundari and Taufiq, 2016; Purwaningrahayu and Kuntyastuti, 2016; Purwaningrahayu et al. 2016; Taufiq et al. 2016). Introduction of improved cultivation technology, such as the use of soybean genotypes, manure application, did not significantly improve soybean yield upto the degree beneficial to the farmers (Purwaningrahayu and Kuntyastuti, 2016; Taufiq et al. 2016). Peanut was also found to be susceptible to saline condition (Wijayanti et al. 2014). However, our field observation showed normal growth of leucaena, banana, grasses and coconut plants along the seashore of East Java. Among the rice varieties, Kurniawan et al (2013) found some varieties were tolerant to saline environment. Variation in saline tolerance was also reported on peanut (Mensah et al., 2006, Nithila et al., 2013) These observations suggest the presence of genotypes of some plant species responsible for tolerance to saline environment. 
Porang (pronounced as 'po-rung') (Amorphophallus muelleri Blume), which is found to naturally grow in tropical forest of Indonesia, has been cultivated commercially by farmers nearby the forest in Java island and other islands of Indonesia (Rofik et al., 2017; Abriyani, 2019; Ahmad, 2019; AlAlawy, 2019; Gesha, 2019; Handayani, 2019; Somantri, 2019). . Porang corms were processed to the dried chips and has been exported to Japan, China, and Korea and Australia (Abriyani, 2019; Ahmad, 2019; Gesha, 2019 and Handayani, 2019). A demand of porang for export could related to the presence of bioactive compounds in the corms. Bioactive compounds contained in the corm of porang were reported to alleviate some illness of human being, such as, cancer, obesity, cholesterol (Yoshida et al., 2006; Yeh et al., 2007; Carlos et al., 2008; Alonso-Sande et al., 2009; Jagatheesh et al., 2010; Soedarjo, 2015). Due to high demand for export, the price of porang is becoming relaively expensive. This high economic value of porang corms has driven farmers to enlarge porang cultivation at nearby the forest, either within the stand of trees or on field without shading. So far, the need for export of porang has not been met due to the lack of porang corm production.

In order to meet the need of export, the Indonesian Ministry of Agriculture has introduced a program to increase corm production of porang (Sugara, 2020). A program on supplying seed in the forms of bulbils or small corms was introduced to expand porang cultivation in Indonesia. Porang is not considered as a main crop Nationally. Thus, the cultivation expansion of porang could be recommended to the sub-optimal soils, such as saline land or swamp land which are abundantly available in most islands of Indonesia. However, the natural growing habitat of porang is forest area, generally considered as fertile soil, is chemically and is physically different from saline or swamp lands. Therefore, an information of porang adaptation on saline and other sub-optimal lands needs to be provided. There has not been any research work of porang done on sub-optimal soils, like saline soil. The present research work was undertaken to discover the growth response of porang on saline soil.

\section{MATERIAL AND MethodS}

\subsection{Plant Material}

The bulbils with different sizes were used in the present study (Fig. 1). The bulbils were harvested from farmer's field at Probolinggo regency, East Java, Indonesia. Before used, the bulbils were stored at room temperature (approximately $28-30^{\circ} \mathrm{C}$ ) from may to October 2019. In October, the shoots of all bulbils sprouted as displayed in Figure 1. The present research work used 8 different sizes of bulbil (see explaination of bulbil sizes on Fig. 1). Bulbils were first germinated on fertile soil (Alfisol) in order to obtain seedling at approximately similar size in each group of bulbil size (Fig. 2). Figure 2 showed that the growth rate of seedling in each group of bulbil size varied. Therefore, similar seedling height in each group of bulbil size was chosen for transplanting.

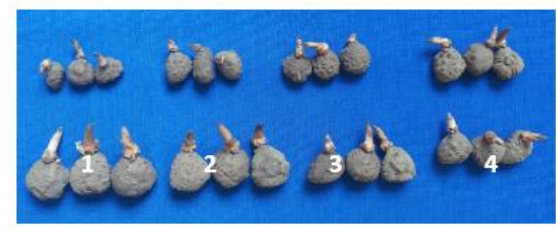

Figure1. Size of bulbil measured as weight/bulbil (g/bulbil): $1=1.88 \mathrm{~g}, 2=2.83 \mathrm{~g}, 3=3.21 \mathrm{~g}, 4=3.75 \mathrm{~g}, 5=$ $4.21 \mathrm{~g}, 6=4.78 \mathrm{~g}, 7=6.45 \mathrm{~g}$ and $8=9.10 \mathrm{~g}$

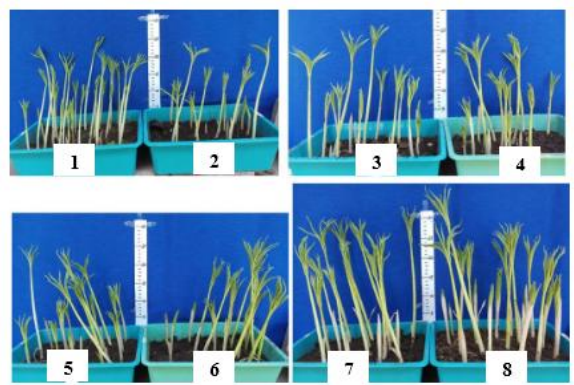

Figure2. Seedling performances before transplanted. Numbers 1, 2, 3, 4, 5, 6, 7, and 8 represent the size of bulbil measured as weight/bulbil (g/bulbil). $1=1.88 \mathrm{~g}, 2=2.83 \mathrm{~g}, 3=3.21 \mathrm{~g}, 4=3.75 \mathrm{~g}, 5=4.21 \mathrm{~g}, 6=4.78 \mathrm{~g}$, $7=6.45 \mathrm{~g}$ and $8=9.10 \mathrm{~g} / \mathrm{bulbil}$ 


\subsection{Soil Preparation, Transplanting and Plant Caring}

Saline and Alfisol soils used in the present research work were obtained from Probolinggo regency, East Java, Indonesia. Alfisol soil from the same site was also used to grow porang seedling as positive control. The soil was analyzed at the Soil and Plant Chemical Laboratory of Indonesian Legume and Tuber Crops Research Institute (ISO/IEC 17025-2017). The soil was air-dried and crushed to pass through $0.5 \mathrm{~mm}$ sieve. Then, the soil of as much as $3 \mathrm{~kg}$ was put into a polyethlylene bag. Before tranplanting the seedling of porang, the soil was watered to a water field capacity. The soil was watered to maximum water holding capacity and was kept overnight to drain out the excess amount of water to attain the water field capacity state. Thus, transplanting was done at one day after. One seedling for each group of bulbil size was transplanted into one polyethelene bag (see Fig. 1 for bulbil size). As comparation, seedlings from the smallest size of bulbil were also transplanted to a polyethlylene bag filled with $3 \mathrm{~kg}$ Alfisol soil.

During the growing period, the saline soil was watered with $5 \%$ sea-water to maintain the salinity at $34.30 \mu \mathrm{S} / \mathrm{cm}$ (Table 1). The 5\% see water was made by diluting 20 times of see water. On the basis of daily obervation, watering was done every two days with $100 \mathrm{ml}$ of $5 \%$ sea water. Porang plants on Alfisol soil were watered with tap water. NPK fertilizer (16:16:16) was applied at rate $300 \mathrm{~kg} / \mathrm{ha}$. Porang seedlings planted on Alfisol soil were similarly fertilized as the seedling planted on saline soil. By considering the plant population of 20,000 per ha (based on field plant spacing $80 \times 60 \mathrm{~cm}$ ), total amount of fertilizer of as much as $15 \mathrm{~g} /$ plant should be used. Fertilizer was planned to be applied 3 times, e.g., 1/3 at planting, 1/3 at 30 days after tranplanting (DAT) and 1/3 at 60 DAT at rate of 5 g/plant, respectively. However, fertilizer was only applied at planting, e.g., $5 \mathrm{~g} / \mathrm{plant}$. It was due to toxicity of the plant on saline soil. Toxicity symptom of salinity appeared at earlier age, before 15 days after transplanting. Since salinity toxicity symptom did not recover at a later stage, the plants grown from different bulbil sizes on saline soil were harvested at age 22 days after transplanting. Porang plants on Alfisol soil were also harvested.

\subsection{Methods}

The present research work was undertaken in the glass house of Indonesian Legume and Tuber Crops Research Institute (ILeTRI) from October to Desember 2019. Each treatment, every bulbil size (1= $1.88 \mathrm{~g}, 2=2.83 \mathrm{~g}, 3=3.21 \mathrm{~g}, 4=3.75 \mathrm{~g}, 5=4.21 \mathrm{~g}, 6=4.78 \mathrm{~g}, 7=6.45 \mathrm{~g}$ and $8=9.10 \mathrm{~g}$.), was arranged in completely randomized design and was replicated three times. Plant height, plant diameter, dry weight of shoot, dry weight of leaves, and dry weight of roots, including the remaining bulbil, were measured to evaluate the effect of salinity. Plant height was measured from the soil surface upto the tip of the shoot. Plant diameter was measured at the shoot right on the soil surface. After harvest, below ground part (root and bulbil), shoot and leaves were oven-dried and weighed. All data of each observation was analyzed by employing Standard Deviation from three replicates.

\section{RESULTS AND DISCUSSION}

\subsection{Soil Chemical Analysis}

The result of soil chemical analysis showed a significant difference in chemical characteristics between saline and Alfisol soils (Table 1). Saline soil has higher soil $\mathrm{pH}, \mathrm{K}^{+}, \mathrm{Ca}^{+2}, \mathrm{Na}^{+}, \mathrm{Mg}^{+}$and electrical conductivity compared to Alfisol soil. The value of $\mathrm{Na}^{+}$(as Cation Exchange CapacityCEC) and EC of saline soil was twice higher than $\mathrm{Na}^{+}$and the EC of Alfisol soil. High $\mathrm{Na}^{+}$and EC of saline soil in East Java was also reported by Sundari and Taufik (2016). Alfisol soil is considered to be fertile soil and characterized with neutral soil $\mathrm{pH}$ and contained higher $\mathrm{N}, \mathrm{K}^{+}$and C-organic than the saline soil.

Table1. Soil chemical properties of saline and Alfisol soils

\begin{tabular}{|l|l|l|}
\hline Chemical properties & Saline soil & Alfisol soil (non-saline) \\
\hline $\mathrm{pH} \mathrm{H} 2 \mathrm{O}(1: 5)$ & 8.30 & 6.20 \\
\hline $\mathrm{N}-$ Total (Kjedahl) $(\%)$ & 0.01 & 0.05 \\
\hline $\mathrm{P}_{2} \mathrm{O}_{5}$ Olsen (ppm) & 147 & 96.50 \\
\hline $\mathrm{K}-\mathrm{NH}_{4} \mathrm{OAc}$ pH $7.0\left(\mathrm{Cmol}^{+} / \mathrm{kg}\right)$ & 0.39 & 0.88 \\
\hline $\mathrm{C}-\mathrm{Org}-$ Walkley \&Black $(\%)$ & 0.76 & 1.15 \\
\hline $\mathrm{Na}\left(\mathrm{Cmol}^{+} / \mathrm{kg}\right)$ & 1.05 & 0.50 \\
\hline
\end{tabular}

International Journal of Research Studies in Agricultural Sciences (IJRSAS) 
Growth Response of Porang (Amorphophallus muelleri Blume) Grown with Different Sizes of Bulbils on Saline Soil

\begin{tabular}{|l|l|l|}
\hline $\mathrm{Ca}\left(\mathrm{Cmol}^{+} / \mathrm{kg}\right)$ & 10.34 & 1.05 \\
\hline $\mathrm{Mg}\left(\mathrm{Cmol}^{+} / \mathrm{kg}\right)$ & 3.88 & 3.94 \\
\hline Electric Coductivity $(\mathrm{EC})(\mu \mathrm{S} / \mathrm{cm})$ & 34.30 & 17.14 \\
\hline
\end{tabular}

\subsection{Plant Height and Plant Diameter at Planting}

At one day after transplanting (DAT), the height and diameter of porang plant was measured and the results were depicted on Figure 3. As expected, the plant height and plant diameter of porang grown from the smallest bulbil were found to be the lowest. Whilst, the plant height and plant diameter of porang grown from the biggest bulbil were found to be the highest. The plant height and the plant diameter are not always significantly different between the bulbil size (see Figure 3). However, bigger size of bulbil was always followed with higher plant height and bigger plant diameter.
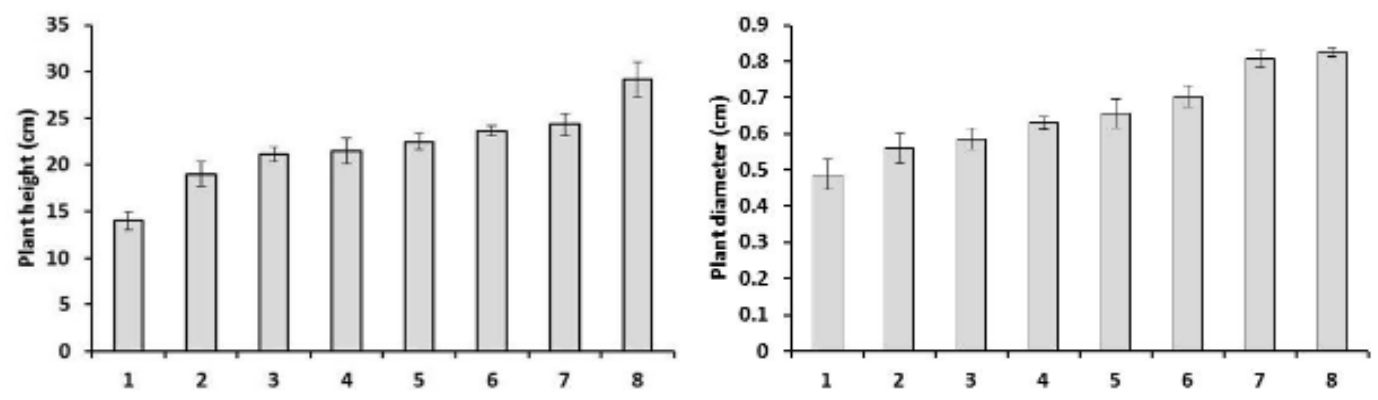

Figure3. Plant height (left) and plant diameter (right) of porang (Amorphophallus muelleri Blume) grown on saline soil at one day after transplanting. Number 1, 2, 3, 4, 5, 6, 7, and 8 represent the size of bulbil measured as weight/bulbil (g/bulbil). $1=1.88 \mathrm{~g}, 2=2.83 \mathrm{~g}, 3=3.21 \mathrm{~g}, 4=3.75 \mathrm{~g}, 5=4.21 \mathrm{~g}, 6=4.78 \mathrm{~g}, 7=6.45 \mathrm{~g}$ and $8=$ $9.10 \mathrm{~g}$.

\subsection{Toxicity Symptoms of Porang Plants at 15 Days after Transplanting}

At 15 days after transplanting (DAT), porang plants showed abnormal growth on saline soil (Figure 4). The symptoms of abnormal growth were indicated with the folding of leaves, slightly brown to dark brown color of leaves, slightly brown to dark brown color of shoot and shoot lodging. The degree of salinity measured as electrical conductivity (EC) and the concentration of sodium of saline soil used in the present work was double than the salinity and sodium of Alfisol. The salinity and sodium of saline soil were observed to be $34.3 \mu \mathrm{S} / \mathrm{cm}$ of EC and $1.05 \mathrm{Na} \mathrm{Cmol}^{+} / \mathrm{kg}$, respectively. In a comparation, the growth of porang at age of 22 days after transpanting on Alfisol soil $(\mathrm{EC}=17.14$ $\mu \mathrm{S} / \mathrm{cm}$ and $0.5 \mathrm{Na} \mathrm{Cmol}^{+} / \mathrm{kg}$ ) (Table 1), was found to be healthy or normal (Fig. 5). The green leaves and shoots were obviously noticed and the plants did not lodge on Alfisol soil. Therefore, the abnormal growth of porang on saline soil, as shown with the symptoms described in this present work, was probably caused by high sodium. High sodium in soil as a main cause to plant growth retardation was well documented elsewhere (Sundari dan Taufiq, 2016; Purwaningrahayu and Kuntyastuti, 2016; Purwaningrahayu et al. 2016; Taufiq et al. 2016).

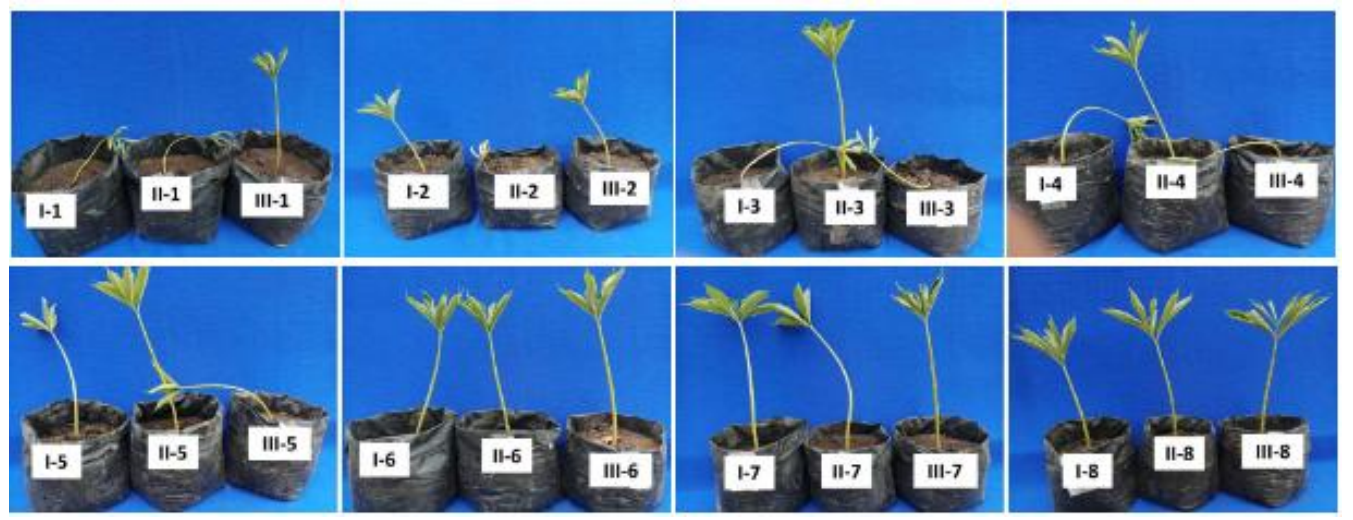

Figure4. The growth of porang (Amorphophallus muelleri Blume) grown on saline soil at age of 15 days after transplanting. Size of bulbil measured as weight/bulbil (g/bulbil): $1=1.88 \mathrm{~g}, 2=2.83 \mathrm{~g}, 3=3.21 \mathrm{~g}, 4=3.75 \mathrm{~g}$, $5=4.21 \mathrm{~g}, 6=4.78 \mathrm{~g}, 7=6.45 \mathrm{~g}$ and $8=9.10 \mathrm{~g}$. Replicatiion was designated with I, II and III. 


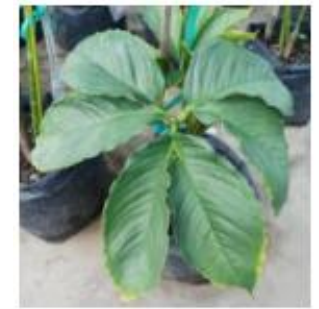

Figure5. The growth of porang (Amorphophallus muelleri Blume) grown on Alfisol soil at age of 22 days after transplanting

Figure 4 also depicted that the severity of toxicity due to salinity varied among the size of bulbil used. Porang plants grown with smallest bulbil size experienced the most severe toxicity of salinity and the porang plants grown with bigger bulbil size (more than $4.21 \mathrm{~g} / \mathrm{bulbil}$ ) showed less saline-associated toxicity symptom. Photo of the porang plants grown from the biggest bulbil size (treatment no. 8) displayed bigger size of the plant organs (leaves and shoots). In ealier growing period, bigger bulbil size would provide more nutrients for growth than the smaller bulbil and resulted in bigger plants. If $\mathrm{Na}^{+}$was a main cause of toxicity to the plant, the less damaging effect of $\mathrm{Na}^{+}$to the porang plant grown from the biggest bulbill size could probably be due to the dilution effect of the plants. Bigger bulbil size produced bigger plants and the bigger plants function as diluting factor. As a result, less toxicity symptom or less damaging effect of $\mathrm{Na}^{+}$to the cells of plant organ.

\subsection{Toxicity Symptom of Plants at Harvest}

Figure 6 showed that the severity of salinty-affected symptoms was more obvious at harvest (22 DAT). Most plants died when the bulbil size used were less than $4.21 \mathrm{~g} /$ bulbil. The growth of porang grown from bulbil size bigger than $4.21 \mathrm{~g} /$ bulbil was severely retarded when compared to the growth at age 15 DAT (see Fig. 3). This result indicates that the plant would not survive on salin soil even though the size of bulbil used was bigger and would eventually die.

At harvest (22 DAT), toxicity symptoms due to saline conditon were also observed on roots, in addition to the shoots and leaves of porang. Salinity associated-toxicity symptoms of the roots were indicated with the brownish color, less number of root and shorter root length when compared with the roots of porang plant grown under non-saline condition, Alfisol soil (left side in each photo of Fig. 6). The plants grown by using the smallest bulbil (number 1) were the most severely damaged. The color of root, shoot and leaves turned to brown, as an indicator that the cells of these organs died. Upto 22 days of age, Figure 6 remained revealing that the damaging effect of saline conditon was found to be less at the bigger size of bulbil. However, all plants grown with bigger bulbil sizes would eventually die when the growing period was kept longer. Toxic effect of saline condition will eventually kill all cells of the roots, shoot and leaves. On the basis of plants performance observed in this research work, it is suggested that porang is susceptible to saline conditon.
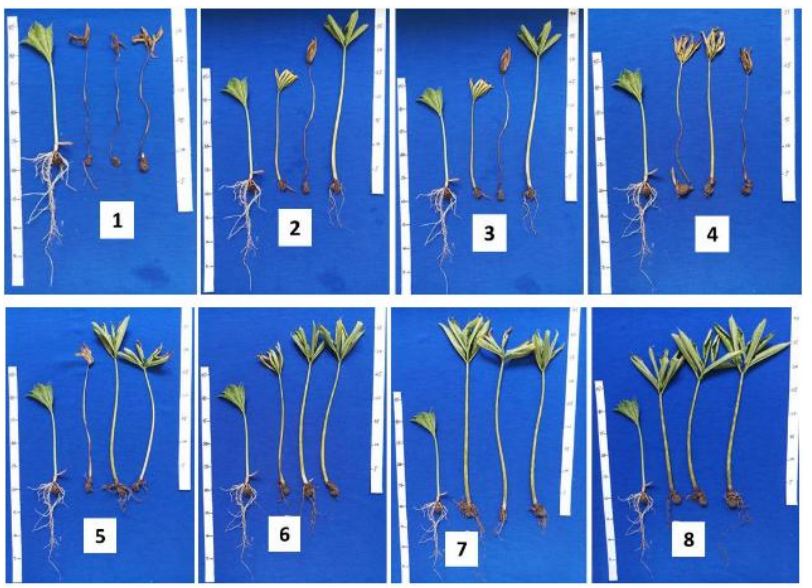

Figure6. Performance of porang (Amorphophallus muelleri Blume) due to the toxicity of saline condition at harvest (22 days after transplanting). At the left most in each photo is porang plant grown on Alfisol soil. The rest in each photo were porang plants grown on saline soil. Size of bulbil measured as weight/bulbil ( $\mathrm{g} / \mathrm{bulbil})$ : $l=1.88 \mathrm{~g}, 2=2.83 \mathrm{~g}, 3=3.21 \mathrm{~g}, 4=3.75 \mathrm{~g}, 5=4.21 \mathrm{~g}, 6=4.78 \mathrm{~g}, 7=6.45 \mathrm{~g}$ and $8=9.10 \mathrm{~g}$. 


\subsection{Sodium Concentration of Root, Shoots and Leaves at Harvest}

Figure 7 depicted that a concentration of $\mathrm{Na}^{+}$in roots, shoots and leaves of porang grown on Alfisol soil (considered to be fertile soil) was much lower than those of porang grown on saline soil. Lower concentration of $\mathrm{Na}^{+}$in root, shoot and leaves of porang grown on Alfisol soil is due to lower concentration of $\mathrm{Na}^{+}$on Alfisol soil (Table 1). Among porang plants grown on saline soil, the concentration of $\mathrm{Na}^{+}$in roots, shoots and leaves varied according to the bulbil size used. The highest concentration of $\mathrm{Na}^{+}$in the roots was associated with the smallest bulbil size. Bigger size of bulbil was followed with lower $\mathrm{Na}^{+}$concentration in root.

In contrary, the concentration of $\mathrm{Na}^{+}$was increasing in the shoots of porang when the bulbil size was higher than $1.88 \mathrm{~g} /$ bulbil. However, $\mathrm{Na}^{+}$concentration in shoot of porang grown with the bulbil size of $2.83 \mathrm{~g} /$ bubil and bigger than $2.83 \mathrm{~g} / \mathrm{bubil}$ did not show a significant increase. Interestingly, the state of $\mathrm{Na}^{+}$concentration in the leaves increased with the increase of bulbil size. The present research work indicated higher translocation of $\mathrm{Na}^{+}$to the leaves with increasing bulbil size. Figure 7 also showed much higher $\mathrm{Na}^{+}$was retained in the shoot than $\mathrm{Na}^{+}$in root or leaves.

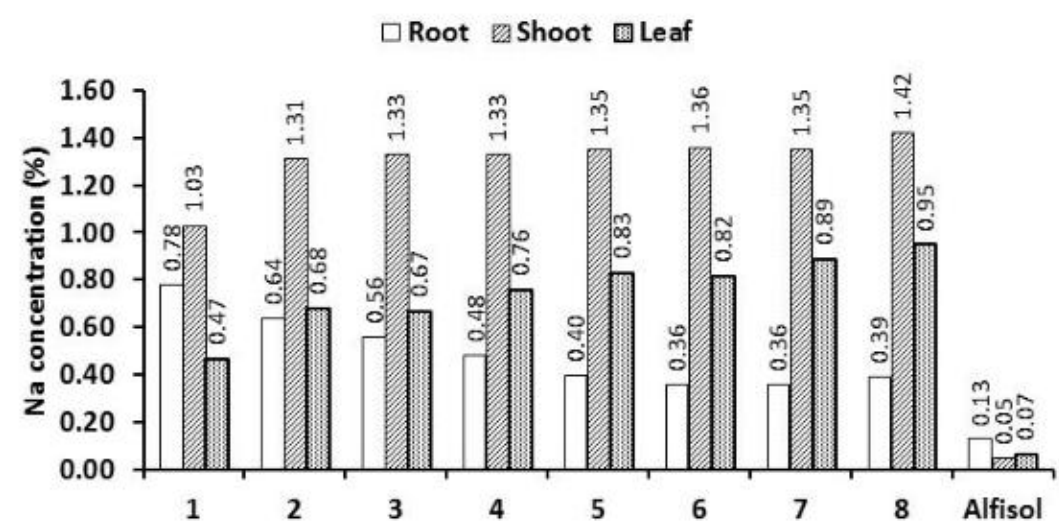

Figure7. Sodium concentration in roots, shoots, and leaves of porang (Amorphophallus muelleri Blume) at harvest (22 days after transplanting) on saline and Alfisol soil. Size of bulbil measured as weight/bulbil $(\mathrm{g} /$ bulbil $): 1=1.88 \mathrm{~g}, 2=2.83 \mathrm{~g}, 3=3.21 \mathrm{~g}, 4=3.75 \mathrm{~g}, 5=4.21 \mathrm{~g}, 6=4.78 \mathrm{~g}, 7=6.45 \mathrm{~g}$ and $8=9.10 \mathrm{~g}$.

Porang plants died much earlier at a treatment of the smallest bulbil size (Figs. 4 and 6). As a result, the nutrient absorped, including $\mathrm{Na}+$, was not further translocated to the shoot and leaves but was retained within the roots. Sodium was eventually accumulated within the roots and caused higher concentration of Na+ (Fig. 7). The bigger size of bulbil resulted in relatively better plant growth and $\mathrm{Na}+$ absorped by the roots was further translocated to the shoots. However, at age of 15 days after transplanting (DAT), all plants suffered abnormal growth due saline toxicity (see Figs. 4 and 6). The abnormal growth of porang plant could drive lower translocation of nutrients, including $\mathrm{Na}+$, to the leaves. Consequently, Na+ would eventually be acculmulated within the shoot and was less translocated to the leaves and resulted in higher and lower $\mathrm{Na}+$ concentration in shoots and leaves, respectively. Our investigation was in parallel to the finding of the previous research works that exposing plants to the saline condition will result in higher $\mathrm{Na}+$ concentration in roots, shoots and leaves of other plant species on saline soil (Maia et al. 2010; Yousif et al. 2010'; Aydinşakir et al. 2015; Fu et al. 2019). Thus, the result of the present research work suggest that porang plant is consdered to be susceptible to saline condiditon.

\subsection{Dry Weight of Leaves, Shoots, Plant (Shoots + Leaves) and Roots}

Figure 8 (left) depicted saline-associated adverse effect on growth of porang plants grown from the smallest bulbil size at harvest (22 DAT). Roots, shoots and leaves dry weights of porang grown on saline soil were significantly lower than those on Alfisol soil. This result sugests that the growth of porang on saline soil was hampered. The percentage of growth retardation by salinity for roots, shoots and leaves was $69.8 \%, 53.5 \%$ and $23.7 \%$, respectively (Fig 8, right). The damaging effet of salinity measured at harvest (22 DAT) on leaves was found to be the least (Fig. 8, right). Figure 7 showed that $\mathrm{Na}^{+}$concentration in leaves, shoots and root of porang grown from the smallest bulbil size were $0.47 \%, 1.03 \%$ and $0.78 \%$. Thus, the least damaging effect of salinity on leave was related to the lowest concentration of $\mathrm{Na}^{+}$in leaves of porang grown on saline soil. The growth retardation of other 
plant species due to salinity or $\mathrm{Na}^{+}$was also reported by several investigators (Neves-Piestun and Bernstein 2001, Maia et al. 2010; Yousif et al. 2010'; Aydinşakir et al. 2015; Sundari dan Taufiq, 2016; Purwaningrahayu and Kuntyastuti, 2016; Purwaningrahayu et al. 2016; Taufiq et al. 2016; Fu et al. 2019).
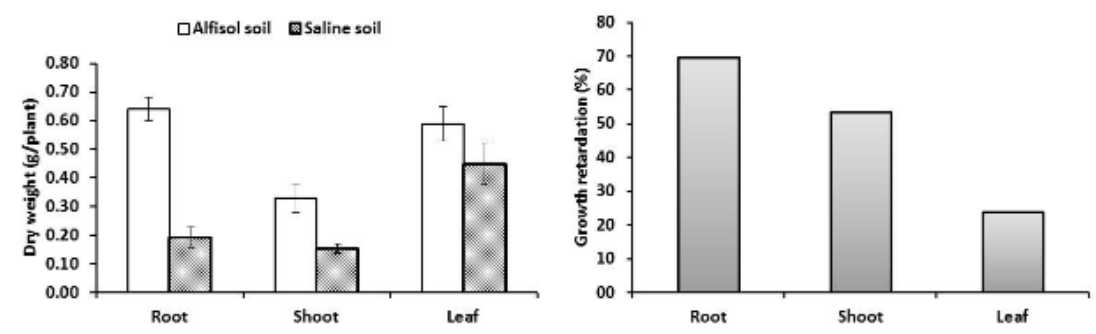

Figure8. Dry weight of root, shoots, leaves of porang (Amorphophallus muelleri Blume) at harvest (22 DAT) grown with the smallest bulbil size on Alfisol soil and saline soil (left) and growth retardation percentage of root, shoots, leaves of porang at harvest due to salinity (right).

Figure 9 depicted an increasing dry weight of leaves, shoots, shoots+leaves and roots of porang at 22 DAT grown from the smallest to the biggest bulbil size on saline soil. Porang plants showed the growth retardation as indicated by toxicity symptoms on 15 and 22 DAT and the percentage of growth retardation (Figs. 4, 6 and 8). Thus, an increase of root, shoot and leave dry weights (Fig. 9) was related to the bigger size of bulbil used in the present researh work. As a planting material, bulbil provides nutrients to the porang seedling that would drive a better growth of root and aerial parts of porang plant at an earlier growing stage. Bigger bulbil size would provide more nutrients and resulting in better growth than the smaller bulbil size. However, porang plants suffered from saline toxicity and showed abnormal growth at early growing stage (Figs. 4 and 6). The abnormal growth seems to be related to $\mathrm{Na}^{+}$toxicity as indicated by significantly higher $\mathrm{Na}^{+}$in roots, shoots and leaves of porang grown on saline soils (Fig. 7). High concentration of $\mathrm{Na}^{+}$in soil and in plant caused damaging effect and failure of harvest (Neves-Piestun and Bernstein 2001, Maia et al. 2010; Yousif et al. 2010'; Aydinşakir et al. 2015; Sundari dan Taufiq, 2016; Purwaningrahayu and Kuntyastuti, 2016; Purwaningrahayu et al. 2016; Taufiq et al. 2016; Fu et al. 2019). This is the first report on the damaging effect of salinity to porang plants and this damaging effect was represented in terms of growth retardation of roots, shoots and leaves (Fig. 8). Besides, we also confirmed that porang (Amorphophallus muelleri Blume) was susceptible to saline soils.
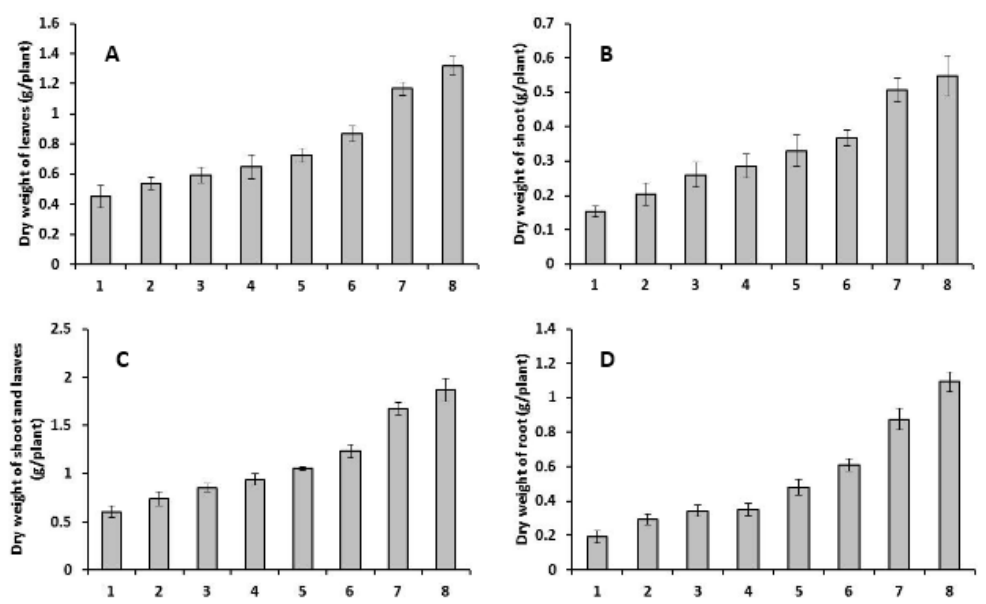

Figure9. Effect of bulbil size on dry weight of leaves $(A)$, dry weight of shoots $(B)$, dry weight of shoots and leaves $(C)$ and dry weight of root $(D)$ of porang (Amorphophallus muelleri Blume) at harvest (22 days after transplanting).grown on saline soil. Size of bulbil measured as weight/bulbil (g/bulbil): $1=1.88 \mathrm{~g}, 2=2.83 \mathrm{~g}$, $3=3.21 \mathrm{~g}, 4=3.75 \mathrm{~g}, 5=4.21 \mathrm{~g}, 6=4.78 \mathrm{~g}, 7=6.45 \mathrm{~g}$ and $8=9.10 \mathrm{~g}$

\section{CONCLUSiON}

The present research work revealed the first report of the growth response of porang (Amorphophallus muelleri Blume) on saline soil. The research findings found that porang planted on saline soil with 
bulbil at sizes from 1.88 to $9.10 \mathrm{~g} / \mathrm{bulbil}$ responded differently. The smallest size of bulbil was found to be the most susceptible to saline condition. At age of 15 days after transplanting, all plants from the smallest bulbil size died. Whilst, porang plants from the biggest bulbil size did not die, but they showed wilting and the leaves folded. However. at age of 22 days after transplanting, severe wilting of all porang plants from all sizes of bulbils was observed. Besides, the roots of all plants from all sizes of bulbils were damaged severely on saline soil. The growth retardation was worst on the root and least on the leaves. In general, our observation suggests that porang was suceptible to saline environment. The chemical analysis of porang plants depicted much higher $\mathrm{Na}^{+}$concentration of porang grown on salin soil than porang grown on Alfisol soil (non-salin soil). Therefore, suceptiblity of porang plant on salin soil is due to toxicity of sodium.

\section{ACKNOWLEDGEMENT}

The undertaking of the present research work was made possible with permission to use the glass house of Indonesian Legume and Tuber Crops Research Institute (ILeTRI), the Indonesian Ministry of Agriculture. Funds was also provided by ILeTRI for soil and plant analysis. The author would like to thank Miss Angesti Purnaningwati and Miss Lia Fani Nugraheni for their assistance in soil and plant analysis. Mr. Abdullah Taufiq is also appreciated for meanigful discussion on salinity.

\section{REFERENCES}

[1] Abriyani A. 2019. Tepung porang di Karangtengah tembus pasar luar negeri (Porang flour at Karangtengah goes to International market) https://www.solopos.com/tepung-porang-di-karangtengahtembus-pasar-luar-negeri-203757 (Accessed 10-10-19)

[2] Ahmad F. 2019. Ekspor ke China dan Jepang-petani NU sukses budidaya tanaman porang (Export to China and Japan-NU farmer successfully cultivate porang). https://www.nu.or.id/post/ read/111187/eksporke-china-dan-jepang--petani-nu-sukses-budidaya-tanaman-porang (Accessed 10-10-19)

[3] Al Alawi M. 2019. Porang Madiun Menjadi Buruan Pengusaha Jepang dan China (Porang in Madiun is a target for the businessman from Japan and China). https://regional. kompas.com/ read/ 2017/ 05/04/ 07080071/porang.madiun.menjadi.buruan.pengusaha.jepang.dan.china?page=all (Accessed 10-10-19)

[4] Alonso-Sande M., D. Teijeiro-Osorio. C. Remuñán-López. M.J. Alonso. 2009. Glucomannan. a promising polysaccharide for biopharmaceutical purposes. Europ. J. Pharmaceutics and Biopharmaceutics 72: 453462.

[5] Aydinşakir K., D. Büyüktaş, N. Dinç and C Karaca. 2015. Impact of salinity stress on growing, seedling development and water consumption of peanut (Arachis hypogaea cv. NC-7). Akdeniz Üniversitesiziraat Fakültesi Dergisi 28: 77 -84

[6] Carlos A., R. Vasques C. A. R., S. Rossetto, G. Halmenschlager, R. Linden, E. Heckler, M. S. P. Fernandez and J. L. L. Alonso. 2008. Evaluation of the pharmaco therapeutic efficacy of garcinia cambogia plus Amorphophallus konjac for the treatment of obesity. Phytother. Res. 22: 1135-1140

[7] Fu Y., Y. Yang, S. Chen, N. Ning and H. Hu. 2019. Arabidopsis IAR4 modulates primary root growth under salt stressthrough ros-mediated modulation of auxin distribution. Frontiers in Plant Sci. 10: 1-15.

[8] Gesha. 2019. Umbi Porang Laku di Vietnam Rp 708.45 Juta (Corms of porang was sold for $R p 708.45$ million in Vietnam). https://tabloidsinartani.com/ detail/industri-perdagangan/ olahan-pasar/8462-UmbiPorang-Laku-di-Vietnam-Rp-70845-Juta (Accessed 10-10-19)

[9] Handayani D. Y. 2019. Ekspor Porang di Jatim Meningkat Dua Tahun Terakhir (Porang export from East Java increased in the last two years). https://kelanakota. suarasurabaya.net/news/2019/223445-EksporPorang-di-Jatim-Meningkat-Dua-Tahun-Terakhir (Accessed 10-10-19:)

[10] Jagatheesh K., V. Arumugam, N. Elangovan and P. P. Kumar. 2010. Evaluation of the anti-tumor and antioxidant activity of Amorphophallus paeonifolius on dmba induced mammary carcinoma. Internat. J. Chem. Pharmaceutic. Sci. 1: 40-50.

[11] Kurniawan S.S., L. A. P. Putri and M. K. Bangun. 2013. Adapatasi beberapa varietas padi (Oryza sativa L.) pada tanah salin (Adaptation of several rice varieties on saline soil). Jurnal Online Agroekoteknologi 1: 249-263.

[12] Maia J. M., E. L. Voigt, C. E. C. Macêdo, S. L. ferreira-silva, J. A. G. Silveira. 2010. Salt-induced changes in antioxidative enzyme activities in root tissues do not account for the differential salt tolerance of two cowpea cultivars. Braz. J. Plant Physiol. 22: 113-122.

[13] Mensah J. K., P. A. Akomeah, B. Ikhajiagbe and E. O. Ekpekurede. 2006. Effects of salinity on germination, growth and yield of five groundnut genotypes. African Journal of Biotechnology 5: 1973-1979. 
[14] Purwaningrahayu R. D. and H. Kuntyastuti. 2016. Efektivitas amelioran dan toleransi genotipe kedelai terhadap salinitas pada tanah salin (Ameliorant effectiveness and tolerance of soybean genotypes on salin soil). Prosiding Seminar Hasil Penelitian Tanaman Aneka Kacang dan Umbi 2016. P. 226-234.

[15] Purwaningrahayu R.D., H. Th. Sebayang, Syekhfani and N. Aini. 2016. Tanggap fisiologis dan hasil biji berbagai genotipe kedelai terhadap cekaman salinitas (physiological and yield responses of some soybean genotypes on salt stress). Buletin Palawija 14: 18-27.

[16] NDSU. 2020. Saline and Sodic Soils.(https://www.ndsu.edu/soilhealth/wp-content/uploads/ 2014/07/Saline-and-Sodic-Soils-2-2.pdf (accessed 09-02-2020)

[17] Neves-Piestun B.G. and N. Bernstein. 2001. Salinity-induced inhibition of leaf elongation in maize is not mediated by changes in cell wallacidification capacity. Plant Physiol. 125: 1419-1428.

[18] Nithila S., D. Durga Devi, G. Velu, R. Amutha and G. Rangaraju. 2013. Physiological evaluation of groundnut (Arachis hypogaea L.) varieties for salt tolerance and amelioration for salt stress. Res. J. Agric. Forestry Sci. 1: 1-8

[19] Rofik K., R. Setiahadi, I. R. Puspitawati dan M. Lukito. 2017. Potensi produksi tanaman porang (Amorphophallus muelleri Blume) di kelompok tani MPSDH Wono Lestari Desa Padas Kecamatan Dagangan Kabupaten Madiun (Yield potential of porang (Amorphophallus muelleri Blume) at farmers cooperative MPSDH Wono Lestari, Padas, Dagangan, Madiun). AGRI-TEK: Jurnal Ilmu Pertanian, Kehutanan dan Agroteknologi 17: 1411-5336.

[20] Soedarjo. M. 2015. Acquisition of the Technique to Analysis of Foods Function Toward Human Health Function and Analysis of these Functions in Indonesian Indigenous Tuber Crops. Postdoctoral Research Report, as a result of mutually beneficial collaboration between Indonesian Agency for Agricultural Research and Development and Kyushu University, Fukuoka, Japan. P. 1-38.

[21] Somantri A. 2019. Dianggap Menguntungkan. Warga Cidadap Sukabumi Berlomba Budidaya Porang (Due to beneficial, farmers cultivated porang). https://sukabumiupdate. com/detail/sukabumi/ekonomidan-bisnis/57483-Dianggap-Menguntungkan-Warga-Cidadap -Sukabumi-Berlomba-Budidaya-Porang (Accessed 10-10-19).

[22] Sugara H. 2020. Kementan dorong madiun kembangkan tanaman porang untuk ekspor (The Indonesian Ministery of Agriculture recommend Madiun regency for porang development). https://monitor.co.id/2020/01/24/kementan-dorong-madiun-kembangkan-tanama n-porang-untukekspor/(Accessed 10-10-19).

[23] Sundari T. and A. Taufiq. 2016. Penampilan Genotipe Kedelai pada Cekaman Salinitas (The performance of soybean genotypes on saline). Prosiding Seminar Hasil Penelitian Tanaman Aneka Kacang dan Umbi 2016. P. 120-126.

[24] Taufiq A., A. Wijanarko and A. Kristiono. 2016. Pengaruh genotipe dan ameliorasi terhadap pertumbuhan dan hasil kedelai pada tanah salin (effect of genotype and soil amelioration on soybean growthand yield in saline soils). Buletin Palawija 14: 1-8.

[25] Wijayanti W., Taryono and Toekidjo. 2014. Keragaan 29 galur kacang tanah (Arachis hypogaea L.) Pada kondisi salin [The Performance of 29 Peanut (Arachis hypogaea L.) lines under saline condition]. Vegetalika 3: 40-51.

[26] Yeh S-L., M-S. Lin and H-L. Chen. 2007. Inhibitory Effects of a Soluble Dietary Fiber from Amorphophallus konjac on Cytotoxicity and DNA Damage Induced by Fecal Water in Caco-2 Cells. Planta Med. 73: 1384-1388.

[27] Yoshida M., C. A. Vanstone, W. D. Parsons, J. Zawistowski and P. J. H. Jones. 2006. Effect of plant sterols and glucomannan on lipids in individuals with and without type II diabetes. Europ. J. Clinic. Nutrit. 60: 529-537

[28] Yousif B. S. Ng. T. Nguyen, Y. Fukuda, H. Hakata, Y. Okamoto, Y. Masaoka and H. Saneoka. 2010. Effect of salinity on growth, mineral composition, photosynthesis and water relations of two vegetable crops; New Zealand Spinach (Tetragonia tetragonioides) and Water Spinach (Ipomoea aquatica). Int. J. Agric. Biol., 12: 211-216

Citation: Muchdar Soedarjo,et.al., " Growth Response of Porang (Amorphophallus muelleri Blume) Grown with Different Sizes of Bulbils on Saline Soil", International Journal of Research Studies in Agricultural Sciences (IJRSAS), vol.6,no. 4, pp.8-16, 2020. Available: DOI: http://dx.doi.org/10.20431/2454-6224.0604002

Copyright: (c) 2020 Authors. This is an open-access article distributed under the terms of the Creative Commons Attribution License, which permits unrestricted use, distribution, and reproduction in any medium, provided the original author and source are credited. 